\title{
ASSESSING THE HUMAN RIGHTS COMMITTEE'S GENERAL COMMENT NO. 37: IS THE INTERPRETATION SUFFICIENT TO PROTECT THE FREEDOM OF ASSEMBLY IN TIMES OF PUBLIC HEALTH EMERGENCY?
}

\author{
Sonia Widya Febriana*
}

\begin{abstract}
Implementing the right of peaceful assembly in the midst of a pandemic seems dangerous, especially when the disease is highly infectious. The United Nations Human Rights Committee then adopted General Comment No. 37 which explains the scope of protection of Article 21 of the International Covenant on Civil and Political Rights 1966. This writing is normative research on the interpretation made by the Human Rights Committee and assessing the sufficiency of the said interpretation in protecting the freedom of assembly in the midst of public health emergencies. It is found that the Human Rights Committee has conducted a thorough method in interpreting the protective scope of Article 21 of the ICCPR, whereas the General Comment No. 37 provides a vast protective scope, including a thorough guideline on how to conduct the freedom of assembly in times of public health emergency.
\end{abstract}

Keywords: $\quad$ Freedom of assembly, general comment no. 37, pandemic, ICCPR, treaty interpretation.

\section{MENILAI KOMEN NO.37 AHLI JAWATAN KUASA HAK ASASI MANUSIA: ADAKAH TAFSIRANNYA MENCUKUPI UNTUK MELINDUNGI KEBEBASAN BERHIMPUN SEWAKTU KECEMASAN KESIHATAN AWAM?}

\begin{abstract}
ABSTRAK
Pelaksanaan hak untuk berkumpul secara aman sewaktu pandemik ini dilihat membahayakan, terutamanya bila wabak ini mudah berjangkit. Jawatankuasa Pertubuhan Bangsa-bangsa Bersatu telah mengambil komen awam no.37 yang menerangkan skop perlindungan Perkara 21

* Student at the International Law Department of Faculty of Law, Universitas Gadjah Mada, Indonesia. Email: sonia.w.f@mail.ugm.ac.id.
\end{abstract}


Konvensyen Antarabangsa mengenai Hak Politik dan Sivil 1966. Makalah ini adalah kajian normatif mengenai tafsiran yang dibuat oleh Jawatankuasa Hak Asasi Manusia dan menilai kecukupan tafsiran tersebut dalam melindungi kebebasan berhimpun sewaktu kecemasan kesihatan umum. Ini menunjukkan Jawatankuasa Hak Asasi Manusia telah melakukan kaedah yang teliti untuk mentafsir skop perlindungan di bawah Perkara 21 ICCPR dan komen am no.37 memberi skop perlindungan yang banyak, termasuklah garis panduan yang teliti mengenai cara untuk melakukan kebebasan berhimpun sewaktu kecemasan kesihatan awam.

Kata kunci: Kebebasan berhimpun, komen am no.37, pandemik, ICCPR, tafsiran perjanjian.

\section{INTRODUCTION}

COVID-19 has taken the world by storm. This highly contagious virus spread like wildfire and people around the world were forced to change the course of their lives. Preventative measures such as lockdowns, wearing masks in public, and social distancing have been imposed in order to stop the virus from spreading.

Those restrictions might put the fulfillment of human rights at stake, and among those rights is the right of peaceful assembly. Holding an assembly during a pandemic that is caused by a highly contagious virus might be deemed unwise. This phenomenon has raised questions; does that mean the right of peaceful assembly can be completely prohibited in ensuring the safety of everyone? If not, how can people hold assemblies without being forcefully dispersed?

At the height of the COVID-19 pandemic, along with questions about the implementation of the right of peaceful assembly that has arisen, the United Nations Human Rights Committee adopted the General Comment No. 37, the Committee's legal interpretation regarding the protective scope of Article 21 of the International Covenant on Civil and Political Rights. The Human Rights Committee embedded the protection of the freedom of assembly in times of public health emergency in the said General Comment, making it a timely contribution since it provides the answers to the questions regarding the enjoyment of the right of peaceful assembly in the midst of a pandemic. 
Treaty interpretation can be intricate since there is no definite method to interpret a treaty - one lawyer's interpretation might differ from another lawyer's interpretation. Even though the Human Rights Committee's General Comments are not legally binding, but they have the ability to persuade States to comply and that persuasiveness can be enhanced by sound reasoning techniques, clear language, and a transparent drafting process. ${ }^{1}$

The right of peaceful assembly is an essential part of maintaining democracy - prohibiting it together is a sign of repressive authority. General Comment No. 37 is a much-needed guideline for States on how to fulfill the right of peaceful assembly even in the midst of a pandemic, but is the interpretation sufficient to safeguard the freedom of assembly?

\section{GENERAL COMMENT NO. 37: HUMAN RIGHTS COMMITTEE'S INTERPRETATION OF ARTICLE 21 ICCPR}

The International Covenant on Civil and Political Rights, or commonly known and abbreviated as ICCPR, is one of the nine core international human rights instruments. The ICCPR is a multilateral treaty that regulates individuals' civil and political rights, including the right of peaceful assembly, which is enshrined in Article 21 of the ICCPR. Human rights treaties, unlike other international treaties, have a unique trait which is how the provisions in human rights treaties entail a greater level of indeterminacy, ${ }^{2}$ which safeguards individuals' rights and States have the obligation to ensure that those rights are protected, whilst other international treaties regulate inter-State relations, and not relations of States with individuals. This unique trait is mentioned by the UN Human Rights Committee in the General Comment No. 24 regarding the implementation of Article 41 of the Covenant, where the Human Rights Committee stated in Paragraph 17 that:

Helen Keller and Leena Grover, "General Comments of the Human Rights Committee and their legitimacy," in UN Human Rights Treaty Bodies: Law and Legitimacy, ed. Helen Keller and Geir Ulfstein (United Kingdom: Cambridge University Press, 2012), 120.

2 James Crawford and Amelia Keene, "Interpretation of the human rights treaties by the International Court of Justice," The International Journal of Human Rights 24, no. 7 (May 2019): 4. 
But the Committee believes that its provisions on the role of State objections in relation to reservations are inappropriate to address the problem of reservations to human rights treaties. Such treaties, and the Covenant specifically, are not a web of inter-State exchanges of mutual obligations. They concern the endowment of individuals with rights.

Due to this distinctive trait that human rights treaties have, the method of interpreting such treaties' articles might differ from the method of interpreting other international treaties.

Interpreting treaties can be complicated and causes great concern among international law practitioners due to differences of opinion regarding the contents of the relevant legal regime currently upheld in international law. ${ }^{3}$ There is no fixed method of interpreting treaties, although the 1969 Vienna Convention on the Law of Treaties (VCLT) does give the general rule of interpretation in Article 31, the supplementary means of interpretation in Article 32, and also the interpretation of treaties authenticated in two or more languages in Article 33. These articles are designed to be indirect and not straightforward on how to understand a treaty in need of interpretation. The purpose of using this law-making strategy is to make the law of the treaty more flexible, ${ }^{4}$ hence it leads to the inexistence of a fixed method of interpreting treaties.

As Robert Kolb said, "interpretation is not a science; it is an art". Lawyers learn to interpret through all the relevant arguments, tools, processes, and underlying values that they gather throughout their lives. ${ }^{6}$ Different outcomes of interpretation will most likely be reached and a reliable normative interpretation might be needed in order to give some substantive content ${ }^{7}$ to the articles contained in the

3 Ulf Linderfalk, On the Interpretation of Treaties: The Modern International Law as Expressed in the 1969 Vienna Convention on the Law of Treaties (The Netherlands: Springer, 2007), 2.

$4 \quad$ Ulf Linderfalk, On the Interpretation of Treaties, 3.

5 Robert Kolb, The Law of Treaties (United Kingdom: Edward Elgar Publishing, 2016), 134.

6 Robert Kolb, The Law of Treaties, 134.

7 Michael Hamilton, "The Meaning and Scope of 'Assembly' in International Human Rights Law," International \& Comparative Law Quarterly 69, no. 3 (July 2020): https://doi.org/10.1017/S0020589320000160. 
treaty. The United Nations Human Rights Committee, which is the sole international body established for the purpose of interpreting the ICCPR,${ }^{8}$ provides reliable interpretation through the General Comments.

The UN Human Rights Committee is one of the human rights treaty bodies sponsored by the United Nations that has the task of monitoring and promoting compliance ${ }^{9}$ with the ICCPR. The Human Rights Committee is a body comprised of 18 independent experts and these members are elected for a term of four years. ${ }^{10}$ According to its Rules of Procedure, the Human Rights Committee has the right to adopt the general comments, which is regulated in Rule 76 paragraph 1 that reads as follows:

The Committee may decide to prepare and adopt general comments on specific topics addressing aspects of the Covenant or its Optional Protocols with a view to assisting States parties in fulfilling their obligations under the Covenant and its Optional Protocols.

The general comments themselves can be defined as the UN human rights expert committee's considered views on an issue that arises out of the provisions of the treaty whose implementation it supervises. ${ }^{11}$ So, it can be said that General Comment No. 37 is the Human Rights Committee's considered views on issues that arise from the implementation of Article 21 of the ICCPR regarding the right of peaceful assembly. The Human Rights Committee then presents those views in the context of a formal statement of its understanding and in essence, the general comments aim to spell out and make the 'jurisprudence' emerging from the Human Rights Committee's work more accessible. ${ }^{12}$ The general comments are also the key to

8 Helen Keller and Leena Grover, "General Comments", 129.

9 Helen Keller and Leena Grover, "General Comments", 116.

10 "Membership," UN Human Rights Committee, accessed November 25, 2020 ,

https://www.ohchr.org/EN/HRBodies/CCPR/Pages/Membership.aspx.

11 P. Alston, "The Historical Origins of the Concept of "General Comments" in Human Rights Law," in The International Legal System in Quest of Equity and Universality: Liber Amicorum Georges Abi-Saab, ed. L. Boisson de Chazournes and V. GowlandDebbas (The Hague: MartinusNijhoff, 2001), 775.

12 P. Alston, "Historical Origins", 775. 
understanding human rights treaty obligations and have been described as 'indispensable' sources of interpretation. ${ }^{13}$

Moreover, the Human Rights Committee also clarified that the intention of the general comments is for the benefit of all State parties in order to promote their implementation of the ICCPR and also to strengthen the cooperation of all States in the universal promotion and protection of human rights. ${ }^{14}$ Another role that the general comments can play is to guide in taking the measures needed to realise rights at the national level, and also establish the normative content of human rights, and give concrete meaning to individual rights and state obligations. ${ }^{15}$ Given the importance of the interpretation, the Human Rights Committee should base their interpretations on the coherent use of an appropriate and accepted method to make them rational and legitimate, and this method can distinguish legitimate determinations of the meaning of a legal rule from arbitrary and random findings. ${ }^{16}$

Interpretation is also an important aspect in implementing the right of peaceful assembly itself. There have been a lot of issues regarding the implementation of the right of peaceful assembly which is legally protected under Article 21of the ICCPR. The most common issue of the right of peaceful assembly is the excessive use of force by law enforcers to disperse the participants of the assembly. Other challenges that revolve around the implementation of the right of peaceful assembly also include, but are not limited to, the arbitrary arrest of assembly participants and also the imposition of excessive liability on assembly organisers. ${ }^{17}$ These challenges surfaced because there has not been a sufficient interpretation of Article 21 that clarifies the protective scope of the said article. Before the introduction of General Comment No. 37, the Human Rights Committee suggested that the guidance with regard to elements of Article 21 is provided in the General Comment No. 34 regarding freedom of expression under

13 Helen Keller and Leena Grover, "General Comments", 118.

14 Helen Keller and Leena Grover, "General Comments", 123.

15 Kerstin Mechlem, "Treaty Bodies and the Interpretation of Human Rights," Vanderbilt Journal of Transnational Law 42, no. 3 (2009): 9058.

16 Kerstin Mechlem, "Treaty Bodies", 908.

17 Michael Hamilton, "Meaning and Scope", 1. 
Article 19 of the ICCPR, but the said guidance does not address the meaning of assembly nor elucidates its autonomous value. ${ }^{18}$

The COVID-19 pandemic that, unexpectedly, has struck the world, has caused such devastating effects with millions of casualties worldwide. Due to the highly contagious nature of the virus, governments all around the world have opted for the 'stay at home and/or 'wear a mask and maintain physical distancing' measures to scale down the ever-increasing number of COVID-19 cases. This is a challenge for the implementation of the right of peaceful assembly since gathering a lot of people to hold an assembly will increase the risk of COVID-19 infection, and yet, on the other hand, the right of peaceful assembly is one of the most fundamental aspects in maintaining democracy; stripping the right of peaceful assembly from individuals could lead to democratic crises, which is already the case in some countries.

The lack of sufficient interpretation regarding the protective scope of Article 21 and also the COVID-19 pandemic that restricts individuals to perform assemblies show that the Human Rights Committee's interpretation, which is General Comment No. 37, was very much needed. The Human Rights Committee finally adopted General Comment No. 37 on July 23, 2020, during the Human Rights Committee's $129^{\text {th }}$ session which was held online. ${ }^{19}$ This is important news because the document can provide the normative scaffolding for all who seek to perform assemblies for many years to come. ${ }^{20}$ The question is: is the interpretation made by the Human Rights Committee through General Comment No. 37 sufficient to protect the right of peaceful assembly, especially during a public health emergency where the risk of contagion, if people gather, is very high?

18 Michael Hamilton, "Meaning and Scope", 2.

19 "General Comment No. 37 on Article 21 of the International Covenant on Civil and Political Rights - Right of peaceful assembly," UN Human Rights Committee, accessed November 27, 2020, https://www.ohchr.org/EN/HRBodies/CCPR/Pages/GCArticle21.aspx.

20 Michael Hamilton, "Meaning and Scope", 28. 


\section{DELINEATING THE PROTECTIVE SCOPE OF ARTICLE 21 AND ITS CONNECTION WITH DEMOCRACY}

As stated before, the ICCPR protects individuals' civil and political rights, including the right of freedom of assembly which is protected under Article 21 that reads as follows:

The right of peaceful assembly shall be recognised. No restrictions may be placed on the exercise of this right other than those imposed in conformity with the law and which are necessary in a democratic society in the interests of national security or public safety, public order, the protection of public health or morals, or the protection of the rights and freedoms of other.

The article stated above does not specify the protective scope nor does it give the definition of the right of the peaceful assembly itself. This is the reason why the implementation of this article varies between State Parties - each State Party might have different interpretations. The reason why there is no restrictive definition regarding assembly in article 21 of the ICCPR is that the Human Rights Committee has shown an openness to the different forms of assembly that have so far been raised about it. ${ }^{21}$ This openness also leads to the overlapping of assembly with protest and demonstration, and also the overlapping of assembly with the right of freedom of expression which is enshrined in Article 19 of the Covenant. International human rights treaties do not feature the terms 'protest' and 'demonstration,' let alone providing a definition to each term and this fact obscures rather than illuminates the distinctive value of each. Protest can be distinguished from the assembly because the declarative element contained in the term 'protest' is absent from the more anodyne term 'assembly. ${ }^{22}$ Moreover, many assemblies are not a form of protest, since assembly may, for example, have celebratory, ceremonial, or commemorative purposes, and many protests do not take the form of an assembly, for example, boycotts, petitions or acts of self-immolation. ${ }^{23}$ Similar to the term

\footnotetext{
21 Michael Hamilton, "Meaning and Scope", 2.

22 David Mead, The New Law of Peaceful Protest: Rights and Regulation in the Human Rights Act Era (Portland: Hart Publishing, 2010), 183.

23 Michael Hamilton, "Meaning and Scope", 5-6.
} 
'protest,' the term 'demonstration' also entails a communicative element that may be absent from an assembly. ${ }^{24}$

Expression, in which the right is protected under Article 19 of the ICCPR, however, is much more difficult to be distinguished from the assembly, and the Human Rights Committee has also emphasised the interdependence of expression with assembly and even has found concurrent violations of Article 19 and Article 21 in more than 30 cases. ${ }^{25}$ This interdependence of freedom of expression and freedom of assembly is also reiterated in Paragraph 4 of the General Comment No. 37 which reads:

The right of peaceful assembly protects the non-violent gathering by persons for specific purposes, principally expressive ones. It constitutes an individual right that is exercised collectively. Inherent to the right is thus an associative element.

This interpretive scope made by the Human Rights Committee derives from the case of Kivenmaa v. Finland, where one of the members of the Human Rights Committee, Mr. Herndl, made a dissenting opinion with the view that properly recognising the intimate and somewhat complex relationship between Articles 19 and 21. ${ }^{26}$ Moreover, Mr. Herndl emphasised that 'the right of peaceful assembly would seem to be just one facet of the more general right to freedom of expression' by citing John P. Humphrey that stated, "there would hardly be freedom of assembly in any real sense without freedom of expression; an assembly is indeed a form of expression." 27

Disentangling freedom of assembly from freedom of expression clearly is not the main focus of the Human Rights Committee in interpreting the protective scope of Article 21, and rather than trying to interpret the right of peaceful assembly's autonomous value, the Human Rights Committee truly emphasises the interdependent nature of the right of expression with the right of peaceful assembly. The protective scope of Article 21, as interpreted by the Human Rights Committee in

24 David Kretzmer, "Demonstrations and the Law," Israel Law Review 19, no. 1 (Winter 1984): 50-1, https://doi.org/10/1017/S0021223700008219.

25 Michael Hamilton, "Meaning and Scope", 6.

26 Kivenmaa $v$ Finland, Views adopted 31 March 1994, UN Doc CCPR/C/50/D/412/1990, Individual opinion by Mr. Kurt Herndl (dissenting), para. 3.3.

27 Kivenmaa, Individual opinion by Mr. Kurt Herndl (dissenting), para. 3.4. 
Paragraph 4 of the General Comment No. 37 and then reiterated again in Paragraph 12 reads:

Participating in an "assembly" entail organising or taking part in a gathering of persons for purposes such as expressing oneself, conveying a position on a particular issue, or exchanging ideas. The gathering can also be intended to assert or affirm group solidarity or identity. Assemblies may, in addition to having such aims, serve other goals, such as an entertainment, cultural, religious or commercial objective, and still be protected under Article 21.

The interdependence of the freedom of expression with the freedom of assembly is also mentioned at the very beginning of the General Comment No. 37, which is in its first paragraph. Paragraph 1 of the General Comment No. 37 states that the right of peaceful assembly is a fundamental human right, and it enables individuals to express themselves collectively and to participate in shaping their societies. Through this General Comment, the Human Rights Committee also asserts the importance of the right of peaceful assembly and its role within a democratic society. This aspect is also mentioned in Paragraph 1 which explains that together with other related rights, the right of peaceful assembly also constitutes the very foundation of a system of participatory governance based on democracy, human rights, the rule of law, and pluralism. The accentuation of freedom of assembly's role within democracy means that States also play a big role in the fulfillment of the right of peaceful assembly. The Human Rights Committee elaborates the obligation of States in Section III of the General Comment.

The matters that are expressed by the participants of the assembly can contribute to shaping society and amplifying the voice of minority groups and sections of society. ${ }^{28}$ In other words, the right to peaceful assembly is also a great advocacy tool to raise awareness. Maina Kiai, a former United Nations Special Rapporteur on the rights to freedom of peaceful assembly and association, stated that the right

28 Neil Jarman and Michael Hamilton, "Protecting Peaceful Protest: The OSCE/ODIHR and Freedom of Peaceful Assembly," Journal of Human Rights Practice 1, no. 2 (June 2009): 208, https://doi.org/10.1093/jhuman/hup011. 
to express grievances or aspirations for change through peaceful protest lies at the heart of any democratic society. ${ }^{29}$

However, the Human Rights Committee's interpretation of the protective scope of Article 21 in this General Comment No. 37 might be seen as restrictive due to the use of the phrase "principally expressive ones." The said phrase, which is written in Paragraph 4 of the General Comment, might be used by the Human Rights Committee to distinguish assembly from random agglomerations. The matter of random agglomerations was brought up by the European Court of Human Rights in the Guide on Article 11 of the European Convention on Human Rights regarding Freedom of Assembly and Association. In Paragraph 14 of the Guide on Article 11, the European Court of Human Rights defined assembly as follows:

Assembly is defined, in particular, by a common purpose of its participants and is to be distinguished from a random agglomeration of individuals each pursuing their own cause, such as a queue to enter a public building. Thus, a group of activists presents outside a courthouse for the purpose of attending a court hearing in a criminal case of a political nature fell within the notion of "assembly" on the basis that by their attendance they meant to express personal involvement in a matter of public importance. The Court distinguished this unintended gathering from a situation where a passer-by becomes accidentally mixed up in a demonstration and is mistaken for someone taking part in it.

The European Court of Human Rights made the interpretation of the scope of assembly based on the case of Navalnyy $v$. Russia. In the said case, the European Court of Human Rights interpreted the issue regarding the forming of a gathering in front of the Zamoskvoretsky District Court, in which the Russian authorities deemed the gathering to be unlawful on the grounds of lack of authorisation. ${ }^{30}$ The Court found that there has been an interference with Navalnyy's right to freedom of assembly because the intention of the said gathering was to express personal involvement in a matter of public importance, hence

29 "2011 - A defining geopolitical moment", OHCHR, accessed 1 December 2020 ,

https://www.ohchr.org/EN/NewsEvents/Pages/2011DefiningGeopolitica Moment.aspx.

30 Navalnyy v. Russia, Application nos. $29580 / 12$ and 4 others, GC Judgment of 15 November 2018, para. 110. 
it needs to be distinguished from a random agglomeration of individuals each pursuing their own cause, such as a queue to enter a public building. ${ }^{31}$

Michael Hamilton, an associate professor of public protest law from the University of East Anglia, argues that the phrase "principally expressive ones" clouds rather than clarifies the scope of the right of peaceful assembly in Article 21 of the ICCPR. ${ }^{32}$ Hamilton argues that even though most assemblies will often be expressive, it is not immediately clear why they need to be expressive to qualify for protection, and also the phrase "principally expressive ones" also assume uniformity of purpose and that could conceal the diversity of motivations, priorities, and views that individual participants are likely to have. ${ }^{33}$ It is also argued by Ashutosh Bhagwat, where he stated that supplementing "expressive association" with the textual right of assembly rejects the pernicious idea that groups deserve protection only to the extent that they are expressive. ${ }^{34}$

Hamilton then suggested replacing the notion of a 'common expressive purpose' with a more straightforward definition of assembly, that also recognises its autonomous standing, and defined assembly simply as an 'intentional gathering. ${ }^{35}$ This simple definition of assembly can distinguish the protected right of peaceful assembly from incidental gatherings, or random agglomerations, ${ }^{36}$ as the European Court of Human Rights has stated. Furthermore, the simple definition suggested by Hamilton might alleviate the restrictive protection scope made by the Human Rights Committee, making the interpretation less rigid.

31 Navalnyy v. Russia, Application nos. 29580/12 and 4 others, GC Judgment of 15 November 2018, para. 110.

32 Michael Hamilton, "Comments on Draft General Comment 37 on Article 21 ICCPR: The Right of Peaceful Assembly," 2020, https://ueaeprints.uea.ac.uk/id/eprint/74650/1/ACADEMIA_Michael_Ha milton.pdf, para. 6.

33 Michael Hamilton, "Comments," para. 7.

34 Ashutosh Bhagwat, "Assembly Resurrected," review of Liberty's Refuge: The Forgotten Freedom of Assembly, by John D. Inazu, Texas Law Review 91, no. 2 (December 2012): 364.

35 Michael Hamilton, "Comments," para. 9.

36 Michael Hamilton, "Comments," para. 9. 
The Human Rights Committee, however, expands the protective scope in Paragraph 12 that says:

Participating in an "assembly" entail organising or taking part in a gathering of persons for a purpose of expressing oneself, conveying a position on a particular issue, or exchanging ideas. The gathering can also be intended to assert or affirm group solidarity or identity. Assemblies may, in addition to having such aims, serve other goals, such as entertainment, cultural, religious, or commercial objective, and still be protected under article 21 .

The Human Rights Committee, in Paragraph 12, enumerates the recognised purposes of holding an assembly, which are (i) expressing oneself, (ii) conveying a position on a particular issue, or (iii) exchanging ideas. Broadening the protective scope, even more, the Human Rights Committee also recognises that those purposes can be accompanied by other goals such as entertainment, cultural, religious or commercial objectives.

This is an improvement from the initial draft that stated commercial gatherings would be covered to the extent that they have an expressive purpose. The broad protective scope in Paragraph 12 might also be able to scratch out the uniformity aspect of the notion of 'common expressive purpose.'

The reason why the Human Rights Committee emphasises the protection of expressive assemblies might be because, in practice, the most common case of violation of the right of peaceful assembly is the excessive use of force to disperse assemblies, especially protests and/or demonstrations that express disagreement towards government's policy; when there is a perceived disparity between what people expect from their governments with what the governments actually deliver. Another common target of authorities' excessive use of force is the assembly organised by the opposition. Disappointment in politics is a familiar experience, people are accustomed to this disappointment due to the hopes unfulfilled. ${ }^{37}$ Holding an assembly can, as mentioned in Paragraph 1 of the General Comment, be used to air grievances and may create opportunities for the inclusive, participatory, and peaceful resolution of differences.

37 Matt Sleat, "Hope and Disappointment in Politics," Contemporary $\begin{array}{lllll}\text { Politics } & 19, & \text { no. } & 2 & \text { (2013): }\end{array}$ https://doi.org/10.1080/13569775.2013.785826. 
Whilst the right of peaceful assembly might contribute and play a great role in shaping the society and is also an important aspect in a democratic society, many cases regarding forced dispersal by law enforcers occurred during the COVID-19 pandemic, in which law enforcers deemed that the pandemic constitutes a public health emergency. 'Public health emergency' is stated in Article 21 of the ICCPR and it is one of the reasons that the right of peaceful assembly can be made derogative. Although it is clear that holding an assembly during a public health emergency could put people's lives in jeopardy, especially the participants of the assembly, does that mean that States could automatically strip this right off of all people and expect their people to just sit back and do nothing while the governments make policies that might threaten the future of their people? Failure to respect and ensure the right of peaceful assembly is typically a marker of repression, as stated in Paragraph 2 of the general Comment No. 37, but is it possible to implement the right of a peaceful assembly during public health emergencies in order to evade democratic crises?

\section{THE IMPLEMENTATION OF THE RIGHT OF PEACEFUL ASSEMBLY DURING PANDEMIC: DEROGATE OR RESTRICT?}

The year 2020 has unexpectedly turned very eventful, especially due to the COVID-19 pandemic hitting relentlessly worldwide and has taken a toll on a lot of aspects, with millions of people having their lives taken by the ferocious virus. This pandemic has also impacted the implementation of human rights. Due to the highly contagious nature and also the fact that there has not been any effective medication to cure COVID-19, governments all around the world have imposed measures to slow down the increasing number of COVID-19 cases such as instructing people to stay at home and also to wear face masks when they have to go out in public. Many people expressed their disagreement with these measures because they feel like their freedom is threatened and their basic human rights are being violated.

Human rights, as we all know, are mandatory to be fulfilled, and States also have the obligation to protect these rights, but it is also important to acknowledge that there are some human rights that are non-derogatory, and also there are some that are derogatory. Nonderogatory human rights, such as the right to life, mean that the rights 
cannot be taken away or compromised, and on the other hand, derogatory human rights, such as the right of peaceful assembly, meaning that the rights, according to the Principle 39 of Siracusa Principles on the Limitation and Derogation Provisions in the International Covenant on Civil and Political Rights, can be taken away or suppressed when faced with a situation of exceptional and actual or imminent danger which threatens the life of the nation. Some human rights might be made derogatory to ensure the fulfillment of nonderogatory human rights, for example, the right of peaceful assembly can be derogated during the COVID-19 pandemic because of the highly contagious nature of the virus, and the derogation needs to be made to ensure the protection of the right to life.

The other reason why some human rights are made derogative by legal drafters is to create a breathing space for States to respond to domestic crises by suppressing individual rights without disobeying the obligations that come with the treaty. ${ }^{38}$ Alternative theories on why States derogate human rights are because it is embedded in the international human rights system, such as the one mentioned in Article 21 of the Covenant, or even derogations as insincere acts. ${ }^{39}$ Moreover, governments need to make convincing reasons regarding the temporary restrictions of rights that are necessary as responses to emergencies. ${ }^{40}$ The derogation model in human rights treaties supplies governments with an 'emergency exit' from obligations provided by the treaties, which put those derogatory rights on hold, or in other words, suspended temporarily. ${ }^{41}$

Temporary derogation on holding assemblies because of the highly infectious virus might sound convincing enough since organising assemblies might threaten the safety and health of the whole population. Indeed, derogation is a legal method as it is enshrined in

38 Emile M. Hafner-Burton, Laurence R. Helfer, and Christoper J. Fariss, "Emergency and Escape: Explaining Derogations from Human Rights Treaties," International Organization 65, no. 4 (October 2011): 703, https://doi.org/10.1017/S002081831100021X.

39 Hafner-Burton, Helfer, and Fariss, "Emergency and Escape," 684-5.

40 Hafner-Burton, Helfer, and Fariss, "Emergency and Escape," 681.

41 Tom R. Hickman, "Between Human Rights and the Rule of Law: Indefinite Detention and the Derogation Model of Constitutionalism," The Modern Law Review 68, no. 4 (July 2005): 658, https://doi.org/10.1111/j.1468-2230.2005.555_2.x. 
Article 4 of the ICCPR, however, States need to follow the mechanism in order to impose a lawful derogation, such as notifying the SecretaryGeneral of the United Nations, ${ }^{42}$ and that the derogation measure shall be such only as are strictly required by the exigencies of the situation.

Unfortunately for some countries, not only are they facing this public health crisis, but they are also facing a democratic crisis, for example in Thailand where the people are trying to enforce democracy and overthrow the military dictatorship that has been reigning for 6 years. Not only Thailand, a fellow ASEAN country, Indonesia, also had a democratic crisis since the government decided to pass the problematic Omnibus Law on Job Creation despite nationwide protests.

Online protest is one alternative to get people's voices to be heard rather than jeopardising the safety through holding an on-ground, face-to-face assembly in public spaces since online protest through social media lowers the barriers required to coordinate ${ }^{43}$ and the cost of protesting online is lower ${ }^{44}$ because there is less effort needed to organise or coordinate as stated before. However, there is a possibility that online protests are more likely to be ignored rather than on-ground protests, and ignoring might lead to people organising on-ground and face-to-face assemblies to amplify their voices through protest. One aspect that also affects the effectiveness of online protests is, while social media allows activists to digitally network with others far and wide, resulting in more people joining the movement, geographical and social proximity provides sufficient levels of solidarity needed to ensure some stability within these movements. ${ }^{45}$ Online movements lack the culture and infrastructure for making collective decisions, and

42 Principle 44 of Siracusa Principles.

43 Zachary C Steinert-Threlkeld, Delia Mocanu, Alessandro Vespignani, and James Fowler, "Online social networks and offline protest," EPJ Data Science 4, no. 1 (December 2015): 2.

44 Zachary C Streinert-Therlkeld, et al., "Online social networks," 8.

45 Sander van Haperen, Walter Nicholls, and Justus Uitermark, "Building protest online: engagement with the digitally networked \#not1more protest campaign on Twitter, "Social Movement Studies 17, no. 4 (2018): 420, https://doi.org/10.1080/14742837.2018.1434499. 
also often fails to signal an organising capacity powerful enough to threaten those in authority. ${ }^{46}$

The Human Rights Committee, through General Comment No. 37, recognises many forms of assemblies, such as demonstrations, protests, meetings, processions, rallies, sit-ins, candlelit vigils, and also flash mobs. ${ }^{47}$ The Human Rights Committee also expands the protective scope of Article 21 to online assemblies. This protection towards online assemblies as mentioned in Paragraph 13 that says:

Although the exercise of the right of peaceful assembly is normally understood to pertain to the physical gathering of persons, article 21 protection also extends to remote participation in, and organization of, assemblies, for example online.

The protection of assemblies involving online activities is also reiterated in Part III of the General Comment that elaborates the obligation of States parties regarding the right of peaceful assembly. This protection is enshrined in Paragraph 34 that states:

Many associated activities happen online or otherwise rely upon digital services. Such activities are also protected under Article 21. States parties must not, for example, block or hinder Internet connectivity in relation to peaceful assemblies. The same applies to geotargeted or technology-specific interference with connectivity or access to content. States should ensure that the activities of Internet service providers and intermediaries do not unduly restrict assemblies or the privacy of assembly participants. Any restrictions on the operation of information dissemination systems must conform with the tests for restrictions on freedom of expression.

This is a huge and important aspect of the protective scope of the right of peaceful assembly, especially to those who cannot organise onground, face-to-face assembly due to the COVID-19 pandemic and have to resort to holding online assembly. This expanded protection can also act as a shield for the participants and/or organisers of the assembly in communicating, such as spreading broadcasts regarding the movement or the assembly itself, against authoritarian regimes that might block or hinder Internet and digital services. Unfortunately, this

46 Zeynep Tufekci, Twitter and Tear Gas: The Power and Fragility of Networked Protest (New Haven: Yale University Press, 2017): 71.

47 Paragraph 6 of General Comment No. 37. 
had been the case in Thailand back in October 2020, ironically, months after General Comment No. 37 was adopted.

Thailand is one of the countries that is enduring a democratic crisis while, at the same time, facing the ruthless COVID-19 pandemic; a crisis within a crisis. The people of Thailand have been protesting for months, demanding the termination of the military junta under the incumbent General Prayuth Chan-Ocha, and also the reform of the Thai monarchy to democratic norms. Measures imposed by the Thai authorities include, but are not limited to, shutting down public transportation to lessen the protests ${ }^{48}$ and the blocking of access to online sites of outlets deemed to be sympathetic towards Thailand's pro-democracy protesters and the restriction of the Telegram messaging app. ${ }^{49}$ The measures imposed by the Thai authorities clearly violate the protection contained in General Comment No. 37, but this is one of the biggest issues with the general comments; the soft law trait that they possess. It means that State parties do not have the duty to fulfill the regulations that are embodied within the General Comments nor does the Human Rights Committee have the power to demand State parties to enforce those regulations in the general comments into state practice.

Another example of a democratic crisis that happened during the COVID-19 pandemic is the atrocious case in Nigeria. People in Nigeria are protesting against violence done by the Special Anti-Robbery Squad (SARS), a special police unit in Nigeria, which has been accused of unlawful arrests, torture, and extrajudicial killings. ${ }^{50}$ Pressured by the demands to terminate the SARS, Muhammadu Buhari, the President of Nigeria, stated that the government has disbanded the SARS and replaced the SARS with the Special Weapons and Tactics (SWAT) team, which disappoints protesters because they see it just as "renaming SARS to SWAT." The peak barbarity of handling the

48 DW News, "Thailand: Bangkok shuts public transport as protests persist", October 17, 2020, https://www.dw.com/en/thailand-bangkok-shutspublic-transport-as-protests-persist/a-55308905.

49 DW News, "Thai police probe 4 broadcasters, restrict Telegram messaging app," October 19, 2020, https://www.dw.com/en/thai-policeprobe-4-broadcasters-restrict-telegram-messaging-app/a-55323161.

50 Al Jazeera, "SARS: Why are tens of thousands of Nigerians protesting?" October 21, 2020 https://www.aljazeera.com/news/2020/10/21/endsarsprotests-why-are-nigerians-protesting. 
protesters in Nigeria happened on Tuesday, 20 October 2020, where the soldiers opened fire and wounded about 25 people, and murdered one person. ${ }^{51}$ This atrocity has attracted more attention to what was happening in Nigeria. António Guterres, the Secretary-General of the UN, issued a statement on 21 October 2020 which calls for an end to reported police brutality and abuses in Nigeria and also urges security forces to refrain from using violence while calling on protesters to demonstrate peacefully. ${ }^{52}$

It is pretty evident that some democratic crises are severe, and protesting through the form of online assembly might be insufficient. As stated before, it may not be powerful enough to threaten those in authority, especially authoritarian regimes. Mr. Clément Voule, the UN expert on the rights to freedoms of peaceful assembly and association emphasised ten key principles regarding the right of a peaceful assembly during the pandemic, in which two of those ten key principles are the most relatable to the derogation due to public emergency matters. The first key principle that is emphasised is ensuring that the public health emergency is not used as a pretext for rights infringements. This principle stresses that a health crisis cannot justify the excessive force used by law enforcers in order to disperse assemblies, nor does it justify disproportionate penalties to be imposed. It also stresses that if a state does a suspension on certain human rights, that derogation measure is, as stated before, mandatory to be reported to the Secretary-General of the United Nations, and also done in compliance with the Siracusa Principles. ${ }^{53}$

The second principle is ensuring that the new legal measures must respect human rights by involving civil society in consultations regarding rights limitation measures and that any limitations of rights must be in accordance with the principles of legality, necessity, and

51 BBC, "End Sars protests: People 'shot dead' in Lagos, Nigeria," October 21, 2020, https://www.bbc.com/news/world-africa-54624611.

52 "Statement attributable to the Spokesman for the Secretary-General - on Nigeria," UN Secretary-General, October 21, 2020, https://www.un.org/sg/en/content/sg/statement/2020-10-21/statementattributable-the-spokesman-for-the-secretary-general-nigeria.

53 "States responses to Covid 19 threat should not halt freedoms of assembly and association," OHCHR, accessed 6 December 2020, https://www.ohchr.org/EN/NewsEvents/Pages/DisplayNews.aspx?News $\underline{\mathrm{ID}=25788 \& \text { LangID }=\mathrm{E}}$. 
proportionality. ${ }^{54}$ This principle is then echoed in Paragraph 36 of the General Comment that stresses:

Authorities must be able to show that any restrictions meet the requirement of legality... The imposition of any restrictions should be guided by the objective of facilitating the right, rather than seeking unnecessary and disproportionate limitations on it.

The Human Rights Committee then provides the limitation guidelines on the right of peaceful assembly in Part IV of the General Comment. As stated in Article 21 of the Covenant, State parties can impose restrictions on the right of peaceful assembly in the interests of national security or public safety, public order (ordre public), the protection of public health or morals, or the protection of the rights and freedoms of others, and the restriction can be imposed as long as it is necessary within a democratic society. The Human Rights Committee explains the conditions when restrictions may be imposed, for each of the reasons embedded in Article 21 of the ICCPR. The imposition of restriction due to public health emergency is regulated in Paragraph 45 of the General Comment that says:

The protection of "public health" may exceptionally permit restrictions to be imposed, for example where there is an outbreak of infectious disease and gatherings are dangerous. This may in extreme cases also be applicable where the sanitary situation during an assembly presents a substantial health risk to the general public or to the participants themselves.

The threat of highly infectious diseases such as COVID-19 is evidently clear and holding gatherings can enhance the danger of the voracious disease. It is reasonable that States might impose restrictive measures to dissuade the number of cases from increasing continuously. State parties of the ICCPR are given the right to permit restrictions to be imposed, as per the Human Rights Committee's interpretation regarding restrictions due to public health emergency, but the Human Rights Committee also emphasises that the restrictions must be applied in the least intrusive measures ${ }^{55}$ and also necessary and proportionate in the context of a society based on democracy, the rule of law, political pluralism and human rights. ${ }^{56}$

\footnotetext{
54 OHCHR, "States responses to Covid 19".

55 Paragraph 37 of General Comment No. 37.

56 Paragraph 40 of General Comment No. 37.
} 
States can, for example, instruct the participants of the assembly to maintain health protocols such as wearing face masks and practising physical distancing. Dire situations like public health emergencies might justify these restrictions, however, States need to pay attention to what kind of restrictions can be imposed. These restrictions must be narrowly construed so as not to unduly impede the free flow of information, ${ }^{57}$ and must also meet the requirement of legality, following the objective of facilitating the right rather than seeking unnecessary and disproportionate limitations as stated in Article 36 of the General Comment. Reiterating these principles in Paragraph 45 by adding, "The restrictions must be formulated in accordance with the principles of legality, proportionality, and necessity" at the end of Paragraph 45 might avoid the imposition of unlawful measures by States that are unnecessary in a democratic society.

Moreover, the Human Rights Committee also grants the possibility for States to limit the number of participants of assemblies in times of public health emergency in which it is necessary to maintain physical distancing. This possibility of imposing a limitation is mentioned in Article 59 of the General Comment. Although the right of peaceful assembly needs to be exercised collectively, every individual has the freedom of assembly, and Article 21 of the ICCPR protects the ability of people to exercise individual autonomy in solidarity with others, as the Human Rights Committee has stated in Article 1 of the General Comment No. 37. Public health emergencies can justify the limitation of participants, ${ }^{58}$ and even though it sounds wrong at a glance, it is better to impose limitations and restrictions, rather than prohibiting the right of peaceful assembly completely.

It can be seen that the Human Rights Committee emphasises the limitation and not derogation in General Comment No. 37, and also affirms the crucial role of the right of peaceful assembly in a democratic society. Derogation measures are not prohibited and may be justified when restrictive measures are not enough to ensure the

57 "Fundamental Rights and the COVID-19 Pandemic," World Justice Project, last modified September 23, 2020, https://worldjusticeproject.org/sites/default/files/documents/fundamental -rights-v4.pdf.

$58 \quad$ Paragraph 59 of General Comment No. 37. 
protection of life and health of individuals in an emergency, ${ }^{59}$ but States also need to ensure that the derogation measures are strictly necessary and guided by the protection of human rights - failing to choose the right approach can lead into more crises than the pandemic itself. ${ }^{60}$

In regards to avoiding repressive actions by law enforcers that might surface during an assembly, especially when there are some restrictions that are imposed on the said assembly, the Human Rights Committee also provides the guidelines regarding duties and powers of law enforcement agencies in Part VI of General Comment No. 37. There have been some cases of repressive acts committed by law enforcers during assemblies in some countries, for example, the protests in Chile that happened back in April 2020. Armed forces were deployed to monitor the assembly, allegedly to help stop the spread of COVID-19, but they were armed with rifles and shotguns, ${ }^{61}$ protesters were met with tear gas and water cannons, and over 60 people were detained on the grounds of infringing public health measures. ${ }^{62}$

The fundamental reasoning on why law enforcers are involved in policing assemblies is to respect and ensure the exercise of the fundamental rights of participants and also to protect them from harm, or in other words, the basic approach of the authorities should be to seek to facilitate peaceful assemblies, as stated in Paragraph 74 of the General Comment. Moreover, the Human Rights Committee emphasises in Paragraph 76 that policing of an assembly should be planned and conducted with the objective of enabling the assembly to take place as intended and to minimise the potential for injury. The use

59 Nadia Rusi and FjordaShqarri, "Limitation or Derogation? The Dilemma of the States in Response to Human Rights Threat during the COVID-19 Crisis," Academic Journal of Interdisciplinary Studies 9, no. 5 (September 2020): 174.

60 Nadia Rusi and FiordaShqarri, "Limitation or Derogation," 174.

61 Gustavo Gatica, "The Chilean police punish us for daring to protest," Amnesty International, October 15, 2020, https://www.amnesty.org/en/latest/news/2020/10/chilean-police-punishus-for-daring-to-protest/.

62 "Civic Freedoms under Threat during the COVID-19 Pandemic: A Snapshot of Restrictions and Resilience," CIVICUS, last modified October 2020 , https://reliefweb.int/sites/reliefweb.int/files/resources/CIVICUSMonitor. COVIDBriefOctober2020.pdf. 
of force must be preceded with prior warning and only the minimum force necessary may be used to de-escalate situations that might result in violence. Furthermore, regarding detainment, the Human Rights Committee stresses in Paragraph 82 that where domestic law permits preventive detention of targeted individuals, it may be used only in the most exceptional cases, which is when authorities have proof of the individuals involved that engaged in or incited acts of violence during a particular assembly. Dispersal of assemblies also may be resorted to when there is clear evidence of an imminent threat of serious violence.

States are ultimately responsible for law enforcement during an assembly ${ }^{63}$ and should consistently promote accountability for law enforcement during assemblies to avoid violent conduct. ${ }^{64}$ These roles are mentioned in Part VI, further reiterating how essential the roles of States are in the fulfillment of human rights.

Moreover, the Human Rights Committee, in providing the guide for duties and powers of law enforcement agencies, also refers to the Basic Principles on the Use of Force and Firearms by Law Enforcement Officials and the United Nations Human Rights Guidance on LessLethal Weapons in Law Enforcement. ${ }^{65}$ This reflects not only the interdependence of human rights but also displays the Human Rights Committee's commitment to showing transparency in their interpreting method. ${ }^{66}$

\section{CONCLUSION}

COVID-19 pandemic has affected a lot of aspects, including the implementation of human rights. Restrictions have been imposed in order to restrain the number of COVID-19 cases, including restrictions on the right of peaceful assembly since COVID-19 is highly infectious in nature, and holding assemblies might worsen and increase the

\footnotetext{
63 Paragraph 93 of General Comment No. 37.

64 Paragraph 89 of General Comment No. 37.

65 Paragraph 78 of General Comment No. 37.

66 Martin Scheinin, "U.N. Human Rights Committee General Comment No. 37 on Freedom of Assembly: An Excellent and Timely Contribution," Just Security, July 30, 2020, https://www.justsecurity.org/71754/u-nhuman-rights-committee-general-comment-no-37-on-freedom-ofassembly-an-excellent-and-timely-contribution/.
} 
number of cases. A public health emergency does not constitute a complete prohibition of human rights implementation, especially the freedom of assembly which is an important aspect in maintaining a democratic society.

This COVID-19 pandemic, however, just intensifies the existing inequalities and injustices due to the system, and the pandemic also points out how emergency politics could cause corrosive effects on democratic institutions. ${ }^{67}$ People from some countries all around the world still hold assemblies as a form of protest, not only because this pandemic has shown the fragility of health systems, ${ }^{68}$ but has also shown the existing inequalities and injustices which lead to democratic crises.

The UN Human Rights Committee, in response to the questions regarding the protective scope of Article 21 of the ICCPR, adopted General Comment No. 37 on the right of peaceful assembly. General Comment No. 37 was adopted during the Human Rights Committee $129^{\text {th }}$ session back in July 2020. The Human Rights Committee has thoroughly interpreted the scope of the right of peaceful assembly, the obligation of State parties regarding the right of peaceful assembly, restrictions, and also duties and powers of law enforcement agencies during assemblies in the General Comment No. 37.

The Human Rights Committee, in General Comment No. 37, has shown their thorough method in interpreting the protective scope of Article 21 of the ICCPR. Not only referring to previous general comments, but the Human Rights Committee also refers to legal cases and also a wide range of guidance documents such as the Siracusa Principles, the United Nations Human Rights Guidance on Less-Lethal Weapons in Law Enforcement, and even the International Code of Conduct for Private Security Service Providers. This displays the interdependence of human rights and also transparency in the Human Rights Committee's interpreting method.

General Comment No. 37 also provides a comprehensive guideline on how to implement the freedom of assembly, even in the

67 AfsounAfsahi, Emily Beausoleil, Rikki Dean, Selen A. Ercan, and JeanPaul Gagnon, "Democracy in a Global Emergency: Five Lessons from the COVID-19 Pandemic," Democratic Theory 7, no. 2 (Winter 2020): 14.

68 Audrey Lebret, "COVID-19 pandemic and derogation to human rights," Journal of Law and the Biosciences 7, no. 1 (January-June 2020): 15. 
midst of public health emergency. It provides a vast protective scope, including the protection of online assembly, and pinpoints that a public health emergency does not constitute the prohibition of the right altogether, but it can be restricted to safeguard people's health and safety. It can be said that General Comment No. 37 is a well-timed contribution.

The soft law nature of the General Comments might be one of the factors that hinder States' compliance with the regulations that are enshrined in the General Comments. Enforcing international law itself can be hard, especially with the absence of authority, but it is not impossible to enforce international law, even without such authoritarian regimes. ${ }^{69}$ The General Comments, acting as secondary soft law instruments, can interpret and add detail to the rights and obligations contained in the respective human rights treaties and as normgenerating instruments, the General Comments can increase the density of international practice on the interpretation of the Covenant and over time could contribute to the emergence of customary international legal norms. ${ }^{70}$ Moreover, as embedded in Article 31(1) of the VCLT, the requirement of interpreting treaties with good faith obliges State parties to duly consider the content of the General Comments, as they are the product of a body established by States parties to interpret the Covenant, as well as to monitor and promote compliance with it. ${ }^{71}$

69 FajriMatahatiMuhammadin, "Can International Law be Enforced Towards its Subjects Within the International Legal Order?" JurnalHukumIusQuiaIustum21, no. 2 (April 2014): 183.

70 Helen Keller and Leena Grover, "General Comments", 129.

71 Helen Keller and Leena Grover, "General Comments", 128. 